\title{
Muslim Consumer Purchase Decisions Based on Persuasion in Advertisement
}

Rosmawati Mohamad Rasit, Azimah Misrom, Siti Jamiaah Abd Jalil, Dewi Angggrayni

To Link this Article: http://dx.doi.org/10.6007/IJARBSS/v11-i10/10053

DOI:10.6007/IJARBSS/v11-i10/10053

Received: 09 August 2021, Revised: 04 September 2021, Accepted: 27 September 2021

Published Online: 15 October 2021

In-Text Citation: (Rasit et al., 2021)

To Cite this Article: Rasit, R. M., Misrom, A., Jalil, S. J. A., \& Angggrayni, D. (2021). Muslim Consumer Purchase Decisions Based on Persuasion in Advertisement. International Journal of Academic Research in Business and Social Sciences, 11(10), 583-593.

Copyright: (c) 2021 The Author(s)

Published by Human Resource Management Academic Research Society (www.hrmars.com)

This article is published under the Creative Commons Attribution (CC BY 4.0) license. Anyone may reproduce, distribute, translate and create derivative works of this article (for both commercial and non-commercial purposes), subject to full attribution to the original publication and authors. The full terms of this license may be seen at: http://creativecommons.org/licences/by/4.0/legalcode

Vol. 11, No. 10, 2021, Pg. $583-593$

Full Terms \& Conditions of access and use can be found at http://hrmars.com/index.php/pages/detail/publication-ethics 


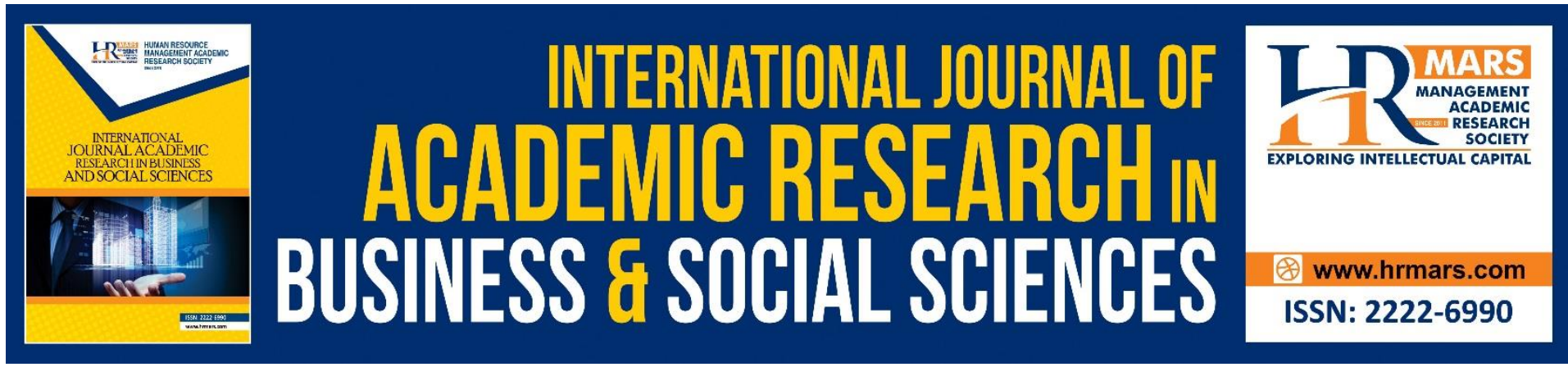

\title{
Muslim Consumer Purchase Decisions Based on Persuasion in Advertisement
}

\author{
Rosmawati Mohamad Rasit, Azimah Misrom, Siti Jamiaah Abd \\ Jalil
}

Research Centre for Dakwah and Leadership, Faculty of Islamic Studies, Universiti Kebangsaan Malaysia, Bangi Selangor

Email: rosmawati@ukm.edu.my, azimahmisrom@gmail.com, sitijamiaah82@ukm.edu.my

Dewi Angggrayni

Programme of Islamic Broadcasting and Communication, Faculty of Islamic Studies Ibn Khaldun University Bogor Indonesia

Email: dewi.anggrayni@uika-bogor.ac.id

\begin{abstract}
Advertisement entices users through the promotions offered. Nevertheless, the advertisements typically confuse consumers whether they purchase their needs or wants. Therefore, this research examined Muslim consumers' views on Muslim consumers' purchasing decisions based on persuasion in advertisements. This study employed phenomenological design through Focus Group Interviews as a method of data collection. A homogeneous group consisted of eight people engaged as study participants. The study analysed data using thematic analysis through Atlas. ti 8.0 software. In essence, the study outcomes obtained three themes on Muslim consumers' views: differentiate between needs and wants, think first before buying, and follow trends.
\end{abstract}

Keywords: Consumer, Muslim, Purchase Decision, Persuasion, Advertisement

\section{Introduction}

Every user has a diverse interest in purchasing a product or service. Purchase decisions regularly depend on several factors, including prices and promotions extended to consumers. Osman et al (2011) asserted that purchase behaviour correlates with determinants that impact consumer purchases, such as promotions, gifts with purchases, free samples, and buy one free one strategy. Nonetheless, some users are deceived by a product through the promotion of advertisements that they see. According to Yoo \& Lee (2009), there is a connection between buying artificial luxury branded products with buying genuine luxury branded products. Consumers will spend without thinking about the amount of money they have to pay as long as they obtain the goods. Consumer buying behaviour also correlates with the sellers' discounted prices (Blackwell et al., 2001). 
Nevertheless, Muslim consumers should make the best choice in the decision-making process, whether to continue the purchase or not. It intends to avoid waste when they buy unnecessary products. Besides, consumers also like to overspend without reasoning the consequences. Such a lifestyle symbolises that they live in luxury that implies deception against consumers when purchasing goods or services. Thus, Osman \& Amimah (2010) maintained that consumers should be smart in making decisions when buying branded goods because the existence of such goods is presently increasing. Furthermore, Mohd Salleh et al. (2008) claimed that a user's behaviour illustrates ways in which individuals decide to manage existing resources such as money, time and knowledge to obtain the desired product or service, such as purchasing activities that eventually determine the type of product, purpose, time and frequency of purchase and its application (Ajzen et al., 2014)

Excessive selection of goods or services prompts consumers to highlight wants over needs. Rai (2013) asserted that consumers believe in various advertising types that promote wellknown products and brands. Consumers will be more likely to buy products or goods by evaluating price rates, with the ones offering risks-free assurance, preferring specific product brands, and looking for diversity in products against existing advertisements and promotions (Mohd Ilham \& Mohamad Salleh, 2015). Furthermore, consumers in Malaysia continuously concentrate on their beauty. Hence, it drives competition for product sales, such as beauty cosmetics in the market. Some consumers take the easy way out by not comparing prices as it involves time, cost and energy to go from one place to another to make price comparisons (Talib, 2017). Rai (2013) said that consumers fancy the quality and price of products advertised and often deceived because of no outlined sales policy (Talib, 2017). Hence, this research examined the views of Muslim consumers on purchasing decisions based on persuasion in advertisements.

\section{Literature Review}

Advertising is employed for marketing purposes, promoting goods and service offerings (Green, 2012). Advertising has played a compelling, persuasive influence on consumers in deciding to buy a product or service (Abbas \& Zamin, 2011). It is possible when information related to a product or service successfully disseminates through pictures or texts. Products or services produced in advertising require promoting, introducing, and providing information, impacting consumers' minds because it endeavours to persuade emotions and impact consumers (Islam \& Alam, 2013; Halim \& Shah, 2010). Further, it intends to help consumers decide to purchase or select a specific product or service (Singh \& Pandey, 2015). Adeel \& Rana (2011) affirmed that advertising acts as a medium that triggers a product and service's needs to inspire consumers to feel an urge to own products and services. Advertising also plays a part in determining consumer buying decisions. Rai (2013) suggested that advertising could influence consumer behaviour based on six advertising principles: to attract attention, promote interest, develop and maintain interest, create desire, encourage action and create good intentions. Advertisements represent lifestyles, tastes, preferences that influence consumers through their behaviour (Thomas, 2007).

Thus, advertisement persuasion influences consumer behaviour, as stated by Rai (2013), in which he believed consumers believe in multiple kinds of advertising that boost the valuation of popular products and brands. Consumers will be more likely to buy products or goods by evaluating price rates, the ones offering risks-free assurance, preferring specific product 
brands, and looking for diversity in products against existing advertisements and promotions (Ilham \& Salleh, 2015). Additionally, Panatik (2004) maintained that consumers exhibit behaviours and dispositions that are loyal to the brand, use intuition, hold an awareness of the latest fashion, prioritise perfection of quality, and uphold the brand's awareness. Burke (1973) demonstrated that a brand works as an exact name for categorising an item. Panatik (2004) continued that awareness of a brand of goods or products could influence a product's consumer choice because consumers obsessed with a brand would consider the brand's value in the selection process before purchase.

Consumers who shop according to a brand have promoted the imitation of products in which Ahmad et al. (2013) declared that the supply of counterfeit products increases and becomes more severe with the rise in its trading value every year. Nevertheless, consumers need to be sensible in deciding when buying essential and branded goods because they increase and harm a corresponding brand with high quality, prestige, and brand (Osman \& Amimah, 2010; Ahmad et al., 2013 ). Therefore, smart consumers need to follow reliable behaviour before making a purchase decision, as described by Harold and John (1978), where purchasing behaviour includes evaluating the price and position of products and quality of goods and the level of satisfaction after purchase. Petty \& Cacioppo (1986) presented the theory of The Elaboration Likelihood Model, in which the advertisement influences users that it decides whether the advertising is effective or not depending on an individual's involvement concerning the ads displayed.

FIGURE 1. Central Route Construct of the Elaboration Likelihood Model (ELM)

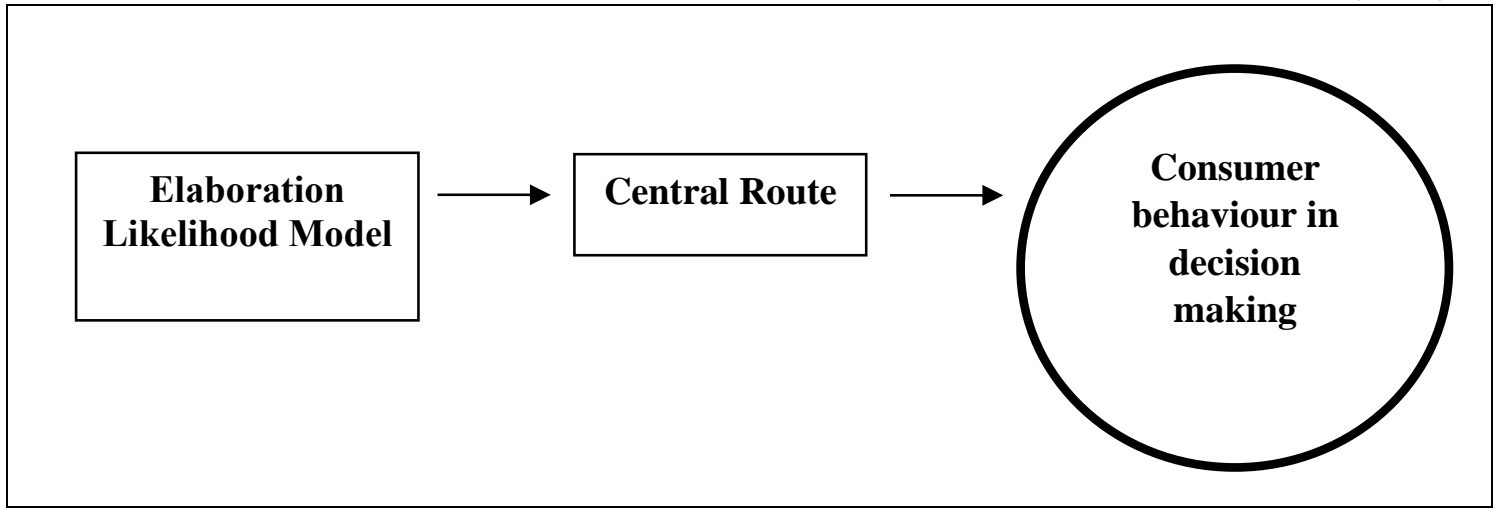

Source: Petty and Cacioppo (1986)

Figure 1 shows the Central Route construct formed and modified from Petty \& Cacioppo (1986). Ghazali et al (2014) affirmed that the Central process occurs when individuals are at a high level of cognitive involvement with high thoughts and knowledge of an issue and are useful in persuading audiences to shift attitudes and behaviours. It also happens when users act cautiously in evaluating information obtained after the issues presented are regarded as essential to the message's recipient (Bryant \& Oliver, 2009). Users also take cares and repeatedly think about the persuasive message they get (Ghazali et al., 2014; Bryant \& Oliver, 2009). The Central Route construct encourages consumers to be more careful before deciding to buy. Furthermore, Adnan (2012) discussed the consumption and demand in Islam, whereby consumers need to be mindful about the type of goods, how to use and their quantity. Besides, al-Qaradawi (2009) affirmed that Muslim consumers should plan purchase by thinking about its halal and haram status before deciding. Thus, Azizan (2011) believed that 
Muslim consumers would practice life according to Islam's appreciation, and it is visible in their shopping taste.

\section{Method}

This study employed a phenomenological design. This research collected the data through a focus group discussion (FGD). A homogeneous group of Muslim consumers involved through objective sampling. A sum of eight study participants engaged based on the set criteria. These criteria were Muslim consumers, working and also watching advertisements for products and services. The study developed a focus group interview protocol containing semi-structured questions to collect qualitative data from study participants. The process of data analysis applied thematic analysis using Atlas t.i 8.0 software to manage the study data.

\section{Results and Discussion}

This research discovered three themes from the views of study participants on their purchase results based on the advertisements they have seen. These themes were to differentiate between needs or wants, think before buying and follow trends. Generally, study participants agreed that their purchasing decisions depended highly on the ads they watched. They were interested in promotions and what the seller offered through advertising. From Muslim consumers' perspective, the persuasion they found through advertisements could attract them to buy a product or service. Through advertising, they learnt more about an item better before deciding to buy it.

\section{Differentiate Between Needs or Wants}

The study's completion found a need to differentiate between needs or wants among Muslim consumers. Persuasion by advertisers often influences consumers to buy a product or service even if it is not a necessity for them. Users strive to meet their needs through the display of the ads they watch. This aspect of decision making is imperative for users to not make the wrong decision due to being influenced by the ad.

Participant 5's View;

... I do not deny that when I buy the goods, (I consider) either the needs or wants, I think there are many wants and needs goods ...

Participant 8's View;

... I will first distinguish needs and wants. The needs are required daily. We need it. On the other hand, needs are not critical. When we see it, (we) want it, but there is no urgent demand for it. For example, (when I see) beautiful clothes. (I will feel the urge to buy it) Even though I have enough of it...

Osman and Amimah (2010) maintained that consumers should be wise in deciding goods to buy. The decision to buy whether the product is necessary and the branded needs to be understood entirely by every consumer. Adnan (2012) claimed that consumers, groups or organisations should make the best use of all available resources such as time, money and effort to optimise satisfaction that includes needs and wants. Therefore, consumers should make wise decisions by distinguishing between needs and wants. According to Jamaludin \& Ramli (2012), manufacturers or distributors use sales gimmicks to draw more consumers to 
buy their goods even though the products produced are low quality and detrimental to consumers. Distributors also offer special offer price packages to entice consumers.

Nevertheless, Muslim consumers believe that persuasive advertisements through attractive advertising displays are not necessarily well perceived. At the same time, it is undeniable that advertising can contribute to shifts in consumer decisions. Some expenses exceed the need when triggered by persuasion in advertisements presented to consumers.

Participant 6 said:

... The ads influence the wants. I have an option, and it is not a must for me to buy it. However, the ads influence me to buy something ...

The participant 6's view of this study proved that Muslim consumers are conscious to spend on wants and needs. Thus, consumers who can distinguish between needs and wants are in line with religious demands. Allah SWT mentioned in surah al-Israa' verse 27, in which it explained that one should not be wasteful in expenses:

Meaning:

“...Indeed, the wasteful are brothers of the devils, and ever has Satan been to his Lord ungrateful.

Whereas, according to Petty and Cacioppo (1986), there is a change of attitude through the process of persuasion. From the central route aspect, decision-making motivates users to make their decisions based on the persuasive factors they get. Therefore, users who get some information can make decisions about what they believe. Based on these considerations, consumers can differentiate what they need in their lives. The central route element is substantial to consumers when they experience a change in attitude due to their judgment and belief in a product or service that they watch through advertisements.

Deciding to purchase a product or service often depends on consumer behaviour circumstances such as lifestyle. Havas (2010) explained this situation. He believed that some consumers are more concerned with wants than values in their life needs. Besides, advertisers aim to make their ads appealing to consumers to purchase their products and submit with the product or service advertised (Tan \& Munira, 2017).

\section{Think First Before Buying}

The results of the study found that there was a theme of 'think first before buying'. The participants stated that before they make a purchase, they need to research first based on price factors, product prospects, and the goods' needs. Study participant 8 mentioned that:

... For example, this week, I intended to buy a rice cooker. I tried to find it in LAZADA. The first (factor that I considered that it must be) cheap, then looked at the brand and saw the quality. For example, when I visited (online shops) and found a cheaper bargain, I bought the cheaper one because I wanted to save some money. That is what I do when I want to buy something...

A wise consumer will always think first before buying and saving in managing expenses. FOMCA (2015) reported that consumers have the right to determine the goods they want to 
buy and compare the price of goods with other stores. Thus, the initial action of researching a product or service offered benefits consumers to buy wisely. The ads displayed are an inherent determinant for a consumer to compare each item they want to buy. Participant 4 said;

... but I will not immediately buy it because I will review the comments first whether the item is right or not, then I will decide whether it is suitable or not...

Participant 7's View:

... advertising certainly plays a role. It changes unnecessary items into the wants that we feel we need, but we do not need it actually...

Waste is one of the attitudes that Islam forbids. In surah al-Israa verse 27, it is stated that wasting is the practice of the devil:

Meaning:

"Indeed, the wasteful are brothers of the devils, and ever has Satan been to his Lord ungrateful.".

Moreover, most consumers now like to buy online because it is easy and fast, but they need to think before buying it. According to Arisah et al (2015), in line with the ever-changing lifestyle changes, online shopping methods are now becoming more prominent among consumers and function as one of the elementary measures to spend to get necessities without having to queue at the counter. It gives consumers the freedom to choose, has information about the goods and services they will buy and obtain prices in line with their level of demand in the market (Jaafar, 2004). A study of how an individual decides to utilise all available resources such as time, money, and effort to acquire consumer-related items (Schiffman \& Kanuk, 2004). Consumers can switch to generic products that are $20 \%$ to $30 \%$ cheaper than FOMCA (2015) branded products. Accordingly, smart consumers need to think first because they can save money and compare prices first before deciding to buy.

\section{Follow Trends}

The theme of 'Follow Trends' is also essential for Muslim users. Based on the study participants' viewpoints, advertisements motivate persuasion to keep them updated with current trends. The ads presented to make the consumers feel the urge to keep up with the trends of life needs. Recent changes in attitudes and lifestyles make users frequently refer to advertisements to keep abreast of current developments. Hence, the ads will stay relevant with time. The persuasive nature of advertising leads them to make better purchasing decisions. Participant 7 stated;

... For me, everyone has the urge to follow the "trend". It is undeniable. For instance, men (may want to keep updated) with gadgets, or maybe clothes, cosmetics or others. So, they may feel that they must have it. So, in my opinion, following the trend is not wrong...

Following the latest fashion trends becomes adults' fixation regardless of student status or careered adults and influencing their lifestyle as consumers or customers (Jampar, 2015). Consumers are sensitive to changes that involve the importance of choosing and buying 
(Panatik, 2004). Jampar (2015) argued that fashion consumers are willing to sacrifice something to meet the lifestyle needs of their choice and be prone to the influence of purchasing behaviour. Consumers today are increasingly aware of the importance of product design, and consumers who buy luxury brands are described as 'self-conscious and try to impress others with them (Penz \& Stottinger, 2005). Therefore, there are imitation luxury branded goods from well-known brands to meet consumers' demands according to affordability but perceived from good quality.

However, some Muslim consumers do not regard this trend as something too significant that it ignores the original purpose of the purchase. Advertising is, of course, an attempt to persuade users to be influenced to make a purchase. Nonetheless, Muslim consumers can also give good judgment on whether the goods are essential or not. They understand the concept of simplicity in purchasing decisions. They think sensibly and not just follow current trends until they get too fixated. Participant 3 said;

... I am not obsessed (following the trend), but I am not "very old fashion". When I go out to do some shopping, I will buy one when I see something that I like. However, I do not purchase something every time I see something new. I do not have the urge to do so. Sometimes, when I see something that I like, I know it is a want, so I can still control myself from buying it...

Islam emphasises awareness of Muslims to adopt the concept of moderation. The concept of moderation needs is to obtain justice and avoid excessive and improper attitudes that become burdensome and inconvenient for oneself and others (Hassan, 2011). Allah SWT mentioned in surah al-Furqan, verse 67 that emphasises that one should be modest in a matter:

Meaning:

"And [they are] those who, when they spend, do so not excessively or sparingly but are ever, between that, [justly] moderate".

\section{Conclusion}

The results of the study show that advertisement plays an important role in persuading consumers to purchase a product or service. Promotions and offers seen in advertisements help users decide whether to buy the product or service or otherwise. The themes in the results, to differentiate needs or wants, to think before buying and to follow the trend, show that consumers' views on their product or service purchasing decisions are influenced by the adverts. In deciding to make a purchase, consumers need consideration of whether it is of a lifestyle or a necessity nature for their lives. Similarly, the theme of thinking before buying shows that consumers are taking a prudent stance and turning promotions and advertising offers as a source of price comparison before making their decision. Consumers also think that 'following the trend' is an important aspect of their lives. However, for Muslim consumers, 'following the trend' is also balanced with the moderation factor in shopping. Muslim consumers still make good judgments when deciding to buy. Muslim consumers adhere to the Islamic teaching of not being wasteful, always being modest and not being extravagant in spending. 
In conclusion, persuasion in advertising can bring about a change in consumer attitudes in making purchasing decisions. This study contributes to the strengthening of the role of persuasion which is seen as important in giving due consideration to Muslim consumers. The analysis shows that every purchase decision of Muslim consumers depends a lot on the advertisements that they watch. Therefore, the production of advertisements should consider the need for a proper advertising message to bring about a change in the buying attitude among Muslim consumers. Through the advertisements, Muslim consumers should be able to distinguish between needs and wants. They should also compare the items they are considering through advertisements. Consumers should make wise decisions by making purchases based on several factors such as the price and prospects of the goods offered.

Ergo, the outcomes confirmed that persuasion in advertising could change consumer attitudes in making purchasing decisions. The role of persuasion is quintessential in giving due consideration to Muslim consumers. Through the advertisements, Muslim consumers should be able to distinguish between needs and wants. They also make comparisons about something they get from ads. Consumers make wise decisions by making purchases based on diverse factors, such as the price and prospects of the goods offered. This analysis determined that every purchase decision of Muslim consumers refers to the display of advertisements they watch. Thus, persuasion in advertising transforms the attitude of buying among Muslim consumers. Nonetheless, Muslim consumers still make sound judgments when they decide to buy something. Muslim consumers adhere to Islamic beliefs so that there is no waste, always practice modesty and be smart in spending.

\section{Acknowledgment}

This Research was Funded by Fundamental Research Grant Scheme (FRGS/1/2017/SSI03/UKM/02/6).

\section{References}

Adnan, A. A. (2012). Islamic Consumer Behaviour: a Discipline or a Sub-Discipline? Journal of Management, 35, $139-149$.

Abbas, A., \& Zamin, R. (2011). Advertisement \& Islam: A Muslim World Perspective. Australian Journal of Business and Management Research, 1 (6), 152-157

Ahmad, I. S., Perumal, S., \& Shaari, H. (2013). Consumer Desire to Buy Counterfeit Luxury Branded Products: A Study in Malaysia. Paper presented at Conference on Business Management Research, December 11, Universiti Utara Malaysia, Sintok.

Ajzen, I., Fishbein, M., Analysis, A. N., Consumer, O. F., To, I., Green, P., \& Caroline, J. (2014). A Peer Reviewed National Journal Consumer Behaviour Models : An Overview. Journal of Experimental Social Psychology, 6 (3), 466- 487.

Arisah, F. M., Badari, Z. S. A., \& Hashim, A. H. (2015). Online Purchasing Practices and Influencing Factors. Paper presented at 19th MACFEA National Seminar 2015. Palm Garden Hotel, IOI Resort City, Putrajaya

Azizan, H. (2011). Young muslims strive for success. The Star, 31 July, 24-25.

Blackwell, R. D., Miniard, P. W., Engel, F. J. (2001). Consumer Behaviour. Orlando: Harcourt College Publishers.

Burke, J. D. (1973). Advertising in the Marketplace. New York: McGraw Hill.

Bryant, J., \& Oliver, M. B. (2009). Media effects, Advances in theory and research. 3rd ed. New York: Routledge. 
FOMCA. (2015). Consumer Power to Set Prices. In. Siti Rahayu Zakaria \& Santhosh Kannan. (Ed.). Ringgit. Selangor: Consumer Research and Resource Centre (CRRC).

Ghazali, S., Mustafa, H., \& Omar, B. (2014). The Effect of Entertainment-Educational Drama and Documentaries in Influencing Intentions to Donate Organs: An Experiment Based on Elaboration Likelihood Model. Malaysian Journal of Communication, 30 (2), 1-20.

Green, J. (2012). Advertising. New York: The Rosen Publishing Group, Inc.

Halim, A. P., \& Shah, M. A. (2010). Perceptions of Rural Muslim Women Towards the Use of Women in Television Advertisements. Retrieved from Eprints.utm.my

Hassan, M. K. (2011). Voice of Islamic Moderation From the Malay World. Ipoh: EMIR.

Harold, H. K., \& John, W. T. (1978). Interpersonal relations: A Theory of Interdependence.

Havas, W. (2010). The new consumer in the era of mindful spending. Prosumer Report 8.

Islam, M. E., \& Alam, M. Z. (2013). Advertising: An Islamic Perpsective. International Journal of Ethics in Social Sciences, 1(1), 105-116.

Jaafar, A. S. (2004). The Position of Consumers in the Post-Modernist Community: Challenges for Malaysia. Paper presented at International Seminar on Values in Post-modenism Community (CIVIC 2004), 4-6 Sept. City Bayview Hotel, Langkawi.

Jamaludin, M. A., \& Ramli, M. A. (2012). Gender Analysis in Current Consumerism Culture According to Islamic Law Perspective. Paper Presented at International Conference on Rights of Muslim Women in the Modern World At: UNISSA Brunei, January.

Jampar, N. F. (2015). Lifestyles Factors Affecting Customers' Impulse Buying Behaviour. Project Paper, Bachelor of Applied Arts.

Salleh, M. N., Othman, M., Paim, L., Nurizan, Y., \& Sabri, M. F. (2008). Consumer Purchasing Behaviour during Rising Prices of Goods in Malaysia. Malaysian Consumer Journal, 10, 45-63.

Ilham, M. N. M., \& Salleh, M. A. (2015). Privacy and Security Issues among Social Media Application Users. e-Bangi Journal, 10 (2), 203-216.

Osman, S., \& Amimah, A. M. (2010). The Influence of Branded Goods on Consumer Purchasing Behaviour. Malaysian Consumer Journal, 14, 10-26.

Osman, S., Benjamin, Y. B., \& Yeoh, F. Y. (2011). Simulation of Sales Promotions Towards Buying Behavior among University Students. International Journal of Marketing Studies, 3(3), 78.

Panatik, S. A. (2004). Decision Making Style Factors in Purchasing Goods. Journal of Technology, 41, 73-91.

Penz, E., \& Stottinger, B. (2005). Forget the 'real' thing-take the copy! An explanatory model for the volitional purchase of counterfeit products. Advances in Consumer Research, 32, 568- 575.

Petty, R. E., \& Cacioppo, J. T. (1986). The Elaboration Likelihood Model of Persuasion. Advances in Experimental Social Psychology, 19, 123-205.

al-Qaradhawi, Y. (2009). Halal and Haram according to Islamic Perspectives. Trans. Muhammad, AJ. 2nd Ed. Johor Bahru: Jahabersa.

Rai, N. (2013). Impact of Advertising on Consumer and Attitude with Reference to Consumer Durable. International Journal of Management Research and Business Strategy, 2 (2), 74-79.

Schiffman, L. G., \& Kanuk, L. L. (2004). Consumer behaviour 8th International Edition. London: Prentice Hall. 
Singh, M., \& Pandey, A. (2015). Effects on Emotional Appeal Used in Television Ads on Purchase Decision of Consumer: A Literature Review. International Education \& Research Journal, 3(5), 176-178.

Talib, K. A. (2017). Consumer Sensitivity and Consumerism in Etnic Circles. In. Talib, KA., \& Zaidi, N. (Ed.). Ethnicity and Consumerism in Malaysia. Bangi: UKM Publisher.

Tan, K. H., \& Munira, N. (2017). Persuasive and Cultural Elements in Billboards and Online Advertising. E-Bangi, Jounal of Science And Humanities. Special Issue 2, 143-151.

Thomas, J. W. (2007). Market Segmentation. Decision Analyst, 1-4.

Yoo, B., \& Lee, SH. (2009). "Buy genuine luxury fashion products or couterfeits?", Advances in Consumer Research, 36, 280-286. 